\title{
Effects of red macroalgal (Gracilariopsis sp.) abundance on eelgrass Zostera marina in Tomales Bay, California, USA
}

\author{
Brittany E. Huntington ${ }^{1,2, *}$, Katharyn E. Boyer ${ }^{2}$ \\ ${ }^{1}$ Romberg Tiburon Center for Environmental Studies and Department of Biology, San Francisco State University, \\ 3152 Paradise Drive, Tiburon, California 94920, USA \\ ${ }^{2}$ Present address: Rosenstiel School for Marine and Atmospheric Science, University of Miami, 4600 Rickenbacker \\ Causeway, Miami, Florida 33149, USA
}

\begin{abstract}
Observations of increasing red macroalgal (Gracilariopsis sp.) abundance in Tomales Bay, California (USA) prompted a field survey and an in situ experiment testing algal mat effects on eelgrass (Zostera marina) growth. At the conclusion of a 3 mo macroalgal enclosure/exclosure study, experimental plots containing high macroalgal loads $\left(1700 \mathrm{~g} \mathrm{~m}^{-2}\right.$ wet weight $=$ mean maximum in a field survey) had significantly lower $Z$. marina shoot densities and growth rates than plots with no algae or with mean algal field abundance $\left(325 \mathrm{~g} \mathrm{~m}^{-2}\right)$. Eelgrass aboveground biomass followed a similar trend, decreasing under high macroalgal loads. We explored possible mechanisms of algal impacts on eelgrass, including changes to redox potential, sediment nitrogen, and light. Of these, light limitation is the most likely explanation for decreases in eelgrass shoot density. Light reaching the benthos where new shoots establish was only $2 \%$ of surface irradiance under high algal loads, while the canopy of adult eelgrass shoots received nearly $40 \%$ of surface irradiance regardless of macroalgal abundance. Reduced $Z$. marina growth rates may also be attributable to light limitation, as light levels neared the compensation irradiance for eelgrass under high macroalgal loads. Phase shifts from seagrass to macroalgae have been well documented in other estuaries, although studies are generally conducted well after the shift to macroalgal dominance has occurred. Our results indicate a similar transition is possible in Tomales Bay and suggest the need to monitor and manage this system prior to a future shift.
\end{abstract}

KEY WORDS: Macroalgae $\cdot$ Bloom $\cdot$ Seagrass $\cdot$ Zostera marina $\cdot$ Tomales Bay

Resale or republication not permitted without written consent of the publisher

\section{INTRODUCTION}

The loss of foundation species, which are habitatmodifying organisms that create physical structure, facilitate key ecosystem functions, and contribute significantly to primary production (Dayton 1972, Bruno \& Bertness 2001), can dramatically impact ecosystem services and diversity (Bellwood et al. 2004, Folke et al. 2004). Seagrasses are the primary foundation species in shallow water estuaries and other soft sediment systems, forming species-rich and highly productive habitats in and on the substratum (Zieman \& Wetzel 1980, Bostrom \& Bonsdorff 2000). Over the last decade, seagrasses worldwide have suffered signifi- cant declines in abundance (Short \& Wyllie-Echeverria 1996, Wyllie-Echeverria et al. 2002). Much of this loss is attributed to human disturbances, namely impacts from watershed development and eutrophication-induced deterioration of water quality (Short \& Burdick 1996, Hauxwell et al. 2003). In response to this global decline, there has been an intensification of research into the detection and assessment of new threats to seagrasses before significant alterations to remaining habitats occur (Cardoso et al. 2004); this pre-emptive approach is especially relevant since long-term recovery of impacted seagrass beds is exceedingly slow or non-existent (Hauxwell et al. 2001, Kendrick et al. 2002). 
Phase shifts to macroalgal-dominated systems have caused profound ecological changes in a variety of coastal habitats (Scheffer et al. 2001), altering total system primary productivity, biogeochemical cycling, and species composition (Borum 1996, Valiela et al. 1997, McGlathery 2001, Schaffelke et al. 2005). Macroalgal blooms can be detrimental to seagrass productivity by forming dense canopies that reduce dissolved oxygen during decomposition (Koch et al. 1990) leading to decreases in redox potential and increases in sediment sulfide and toxic ammonium concentrations (Van Katwijk et al. 1997, Terrados et al. 1999, Lamote \& Dunton 2006). In addition, algal blooms can shade seagrasses, hindering shoot growth and survival (Hauxwell et al. 2001, Havens et al. 2001, Brun et al. 2003). Such alterations can propagate upward through the food chain to negatively affect primary and secondary consumers that rely on seagrasses for habitat, food or shelter (Bostrom \& Bonsdorff 2000, Cummins et al. 2004, Thomsen \& McGlathery 2006).

Studies documenting the phase shift from seagrasses to macroalgae have been conducted in highly eutrophic systems where the shift to macroalgal dominance had already occurred (Short \& Burdick 1996, Hauxwell et al. 2001, Cardoso et al. 2004). Studies exploring the initial stages of phase shifts in seagrass systems are lacking, though much can be learned about the erosion of ecosystem resilience before the collapse of a foundation species. This absence of primary literature documenting the early stages of phase shifts is not surprising given that initial changes to ecosystems are subtle and 'early warning signals' are difficult to detect (Scheffer et al. 2001). Yet identifying these early indicators in locations that are 'pre-phase shift' and then tracking their progression will aid our understanding of how systems approach catastrophic change and may provide opportunities to intervene before a systemwide shift occurs.

It is important to note that the relationship between macroalgal mats and seagrass health varies among published studies. The extent to which macroalgal accumulation influences (both spatially and temporally) the dynamics of the relationship is moot. For example, Hauxwell et al. $(2001,2003)$ attributed seagrass loss to shading by Gracilaria spp. canopies $9 \mathrm{~cm}$ tall, while Bell \& Hall (1997) found that neither Gracilaria spp. cover nor biomass ( 2000 $\mathrm{g} \mathrm{m}^{-2}$ wet weight) were significantly related to seagrass density and production. Irlandi et al. (2004) measured a $25 \%$ reduction in seagrass aboveground biomass under massive macroalgal drift loads (2000 $\mathrm{g} \mathrm{m}^{-2}$ wet weight), yet detected no negative impacts on seagrass growth, shoot density or belowground biomass in the same experimental plots during a 3 mo period. Cummins et al. (2004) examined the impacts of macroalgal mats $\left(\sim 4500 \mathrm{~g} \mathrm{~m}^{-2}\right.$ wet wt) on seagrass productivity, finding a significant negative response despite the small spatial scale $\left(1 \mathrm{~m}^{2}\right.$ plots) and relatively short duration (3 mo) of the experiment. It is likely that a threshold of high macroalgal biomass must be achieved to trigger the transition from seagrass to macroalgal dominance, with the absolute seaweed abundance required dependent on location, algal and seagrass species, and perhaps numerous other factors. Further, there may be positive effects of algal mats on estuarine vascular plants that balance negative effects (Gerard 1999), possibly through nutrient subsidy (Tyler et al. 2001, Boyer \& Fong 2005). Hence, the effect of algal mats on particular seagrass growth characteristics at any given time or location are difficult to predict.

Tomales Bay is a relatively undeveloped, temperate embayment in northern California with historically healthy meadows of the eelgrass Zostera marina that cover $3.9 \mathrm{~km}^{2}$ of the $20 \mathrm{~km}$ long bay (Spratt 1981, Fig. 1). Many of the Tomales Bay eelgrass beds are intertidal, becoming completely exposed during low

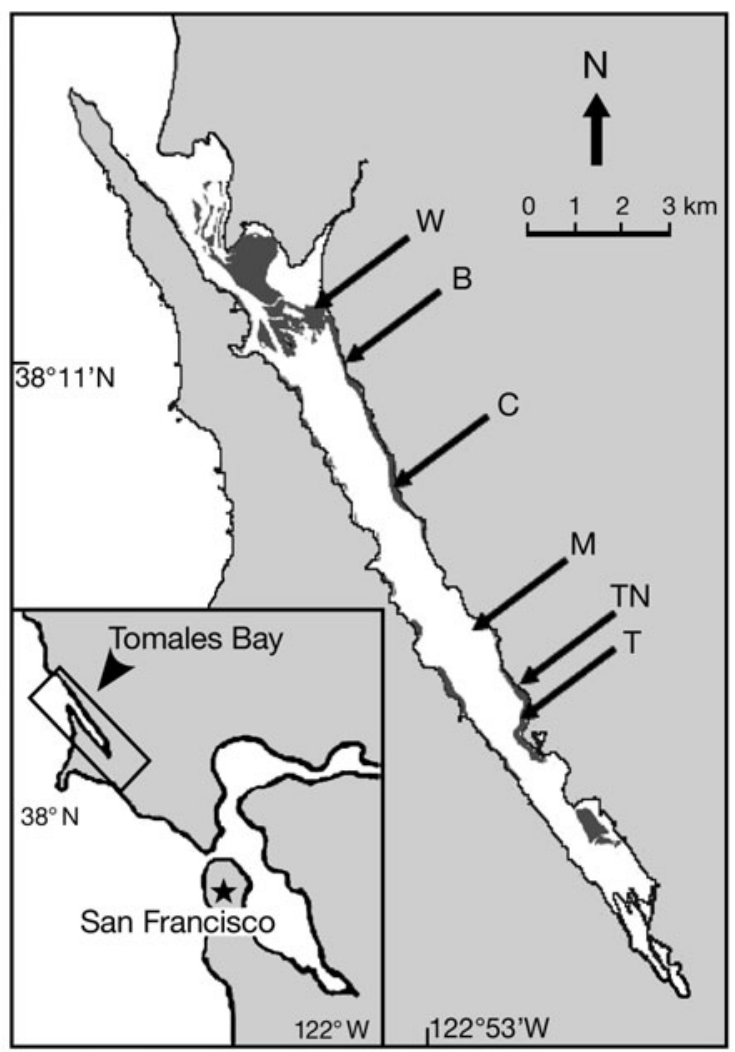

Fig. 1. Location of study sites in Tomales Bay. $\square$ depict areas of existing eelgrass cover according to the California Department of Fish and Game surveys in 1992, 2001, and 2002. W = Walker Creek, B = Big Tree Cove, C = Cypress Grove, $\mathrm{M}=$ Marconi Cove, $\mathrm{TN}=$ Tomasini Cove North, and $\mathrm{T}=$ Tomasini Cove. Enclosure/exclosure experiment was located at B 
tides. In recent years, monitoring in Tomales Bay shallow eelgrass beds by the California Department of Fish and Game (CDFG) has detected a shift in species composition among the benthic primary producers (T. Moore pers. comm.). Areas previously dominated by eelgrass now co-exist with large abundances of the native macroalga Gracilariopsis sp. (putatively G. andersonii). This macroalga occurs in clumps anchored to small pebbles among eelgrass shoots, but the seaweed can also accumulate in large mats that rest on the sediments within the eelgrass beds. The effects of this increased macroalgal presence on $Z$. marina are unknown. Using a combination of site surveys and a dosage-response in situ enclosure/exclosure experiment, we investigated the impacts of varying abundances of Gracilariopsis on Z. marina. Our primary objectives were to explore patterns of Gracilariopsis abundance and its effects in intertidal eelgrass beds at within-site and among-site (bay-wide) scales and to test experimentally the effects of average and maximum algal densities on eelgrass growth responses and abiotic conditions. In doing so, we identified fine scale shifts in primary producers that may be subtle signs of weakening ecosystem resilience undetectable at a coarser, bay scale.

\section{MATERIALS AND METHODS}

Distribution and abundance surveys. Surveys were conducted in June 2005 at 6 intertidal sites along the length of Tomales Bay to quantify the abundance of Gracilariopsis in relation to Zostera marina abundance (Fig. 1). Preliminary macroalgal and eelgrass collections along both shorelines (see Huntington 2006) indicated that the western shore of Tomales Bay had limited biomass of both macrophytes within the intertidal range. In contrast, the eastern shore had extensive intertidal eelgrass cover and notable macroalgal abundances (perhaps due to the prevailing westerly wind pushing macroalgal mats into shallows along the eastern margin). Hence, all 6 survey sites were selected along the eastern shore where potential impacts from changing macroalgal abundances would be greatest.

At each survey site we established 3 parallel $50 \mathrm{~m}$ transects spaced $5 \mathrm{~m}$ apart within continuous seagrass habitat. At 4 randomly selected points along each transect, all Gracilariopsis thalli within a $0.25 \mathrm{~m}^{2}$ quadrat were collected, cleaned of invertebrates and debris, and spun in a salad spinner for $1 \mathrm{~min}$ to remove excess water. We report wet weight of the cleaned macroalgae to best represent field abundances and for ease of relating these quantities to those used in an in situ macroalgal enclosure experiment. We counted all
Zostera marina shoots per quadrat and measured the longest leaf length per shoot.

Correlation analyses between Gracilariopsis abundance and Zostera marina shoot density were explored at 2 spatial scales: among-site [comparing quadrat averages from all 6 sites surveyed bay-wide (Fig. 1)] and within-site (comparing between quadrats at any given site). Additionally, correlation analyses at the among-site scale were used to test for relationships between Gracilariopsis abundance and distance from the mouth of the bay. Linear trendlines were fitted when significant results were found and adjusted $r^{2}$ values are reported.

Enclosure/exclosure experiment. To test the effects of Gracilariopsis mats on eelgrass, macroalgal enclosure/exclosure experimental plots were established in an intertidal eelgrass bed at Big Tree Cove (Fig. 1) selected for its extensive eelgrass cover and intermediate density of Gracilariopsis (see Fig. 3). Prior to the establishment of the experiment, a preliminary tagging experiment was conducted at the site to evaluate the residence time of Gracilariopsis mats within the intertidal eelgrass bed, as the greatest impact would be expected if mats remain in place for extended periods of time. Existing mats $>1500 \mathrm{~g}$ wet weight were tagged by attaching labeled flagging tape to a section of the macroalgal thallus in early July 2005. Initial position of the mat was marked with a labeled bamboo stake driven into the sediment next to the mat. We determined that all tagged mats $(n=5)$ were located in the same position over the 3 mo monitoring period (Huntington 2006) during the summer/fall season.

The enclosure/exclosure experiment was run for 3 mo in late summer/fall (August 5 to November 15, 2005) when growth rates of Zostera marina are high due to increased water temperatures and light availability (Fourqurean et al. 1997). Three macroalgal addition treatments were established, representing the range of Gracilariopsis biomass (wet weight) found within the bay during the distribution and abundance surveys: $0 \mathrm{~g} \mathrm{~m}^{-2}, 325 \mathrm{~g} \mathrm{~m}^{-2}$ (the average of the 6 surveyed sites), and $1700 \mathrm{~g} \mathrm{~m}^{-2}$ (greatest average biomass found at any one site). Treatment plots $\left(1 \mathrm{~m}^{2}\right)$ were enclosed with PVC frames strung with clear monofilament netting $(0.95 \mathrm{~cm}$ mesh size $)$ to ensure the enclosure/exclosure of macroalgae while minimally reducing water circulation or irradiance. Prototype enclosures indicated that no roofs were needed on the frames to retain Gracilariopsis. A cage control was established consisting of a PVC structure without monofilament mesh and no algal addition. A final control treatment consisted of unaltered eelgrass/algal habitat. All 5 treatments were replicated 6 times for a total of 30 plots. Plots were arranged in a randomized 
complete block design, to account for increasing depth across the experimental area, with $3 \mathrm{~m}$ between all plots and blocks.

To compare initial sediment characteristics among blocks, 3 cores (5.2 cm diameter, $10 \mathrm{~cm}$ deep) were collected from each block, dried to constant weight, ground, sieved, and analyzed for organic content (loss on ignition, $500^{\circ} \mathrm{C}$ for $3 \mathrm{~h}$ ), $\% \mathrm{C}$, and $\% \mathrm{~N}$ ( $\mathrm{CHN}$ analyzer). We cut rhizomes to a depth of $20 \mathrm{~cm}$ around the perimeter of all plots to isolate shoots within the plot from those outside (Lee \& Dunton 2000). Plots were visually checked throughout the experiment to ensure macroalgae maintained initial treatment levels. Midway through the experiment, a second mass of macroalgae (either $1700 \mathrm{~g}$ or $325 \mathrm{~g}$ ) was added to the algae remaining in the plots to compensate for senescence and cage leakage (Irlandi et al. 2004).

Eelgrass shoot density and growth rate were measured within the enclosures every 3 to $4 \mathrm{wk}$. Initial density was measured on August 5, 2005 using a $50 \mathrm{~cm}$ $\times 50 \mathrm{~cm}$ subplot centered in the middle of each experimental plot prior to the application of the macroalgal treatments. Eelgrass response sampling (25 August, 17 September, and 13 November, 2005) employed a $30 \mathrm{~cm} \times 30 \mathrm{~cm}$ subplot. To evaluate eelgrass growth rates $\left(\mathrm{mg}\right.$ shoot $\left.^{-1} \mathrm{~d}^{-1}\right)$, approximately 10 shoots per plot were marked using a 22-gauge hypodermic needle (Zieman \& Wetzel 1980). A single hole was punched through haphazardly selected shoots just above the meristem; these were collected 2 to $3 \mathrm{wk}$ later and the new biomass between the constant meristem position and the punched hole was weighed. In addition, to estimate aboveground shoot biomass, we measured longest leaf length of 20 haphazardly selected shoots per plot. Longest leaf length was determined to be a reliable proxy for aboveground shoot biomass (sensu Hauxwell et al. 2001); 92 randomly selected shoots collected from the Cypress Grove Preserve eelgrass bed in Tomales Bay yielded a significant positive linear relationship between shoot wet weight and longest leaf length (Model 2: Reduced Major Axis regression, $\mathrm{p}$ $\left.<0.001, \mathrm{r}^{2}=0.844\right)$.

During the third week of the experiment, a LI-COR 1000 data logger with a LI-193 spherical quantum sensor was used to quantify the reduction in photosynthetically active radiation (PAR) reaching the eelgrass canopy as well as the benthos in each plot. Measurements were conducted when plots were covered with $70 \mathrm{~cm}$ of water and light readings were taken $50 \mathrm{~cm}$ above the benthos (corresponding to average height of the established seagrass canopy) and $5 \mathrm{~cm}$ above the sediment surface to measure light reaching new shoots.

At the conclusion of the experiment, we tested for changes in redox potential relative to algal treatment.
Platinum-tipped electrodes were used to take 10 readings per plot to a depth of $3 \mathrm{~cm}$ after equilibrating for $10 \mathrm{~min}$. The potential of a calomel reference electrode against a standard hydrogen electrode $(+245 \mathrm{mV})$ was added to each measured value; the 10 values from each plot were averaged. Final sediment cores (3 subsamples per plot) were taken within a centered $30 \mathrm{~cm}$ $\times 30 \mathrm{~cm}$ subplot to avoid potential edge effects, and analyzed in a manner identical to that for initial sediment samples.

Block differences were examined prior to application of treatments and at the conclusion of the experiment for sediment characteristics (nutrient and organic content) and eelgrass response variables (shoot density and aboveground biomass). Block effects were never significant (1-factor ANOVA, p > 0.42, 0.34, and 0.50 for initial sediment, final sediment and final eelgrass characteristics, respectively), and blocking was dropped from subsequent analyses.

Final sediment properties were analyzed using 1-factor ANOVA. PAR values were analyzed using 2-factor ANOVA (treatment $\times$ depth of light reading). Repeated measures ANOVAs were used to analyze eelgrass response variables across sampling dates, with Greenhouse-Geisser adjusted p-values reported for the within subject effects. Additionally, 1-factor ANOVAs (factor: macroalgal treatment) were run on eelgrass response variables at the conclusion of the experiment. For all ANOVAs, Levene's test of homogeneity of variances was used and log transformations were performed to stabilize variance, as needed. Fisher's PLSD test was used for pairwise comparisons among treatment means after significant $(\mathrm{p}<0.05)$ ANOVA tests.

\section{RESULTS}

\section{Distribution and abundance surveys}

The intertidal eelgrass beds in Tomales Bay were mainly continuous; only 1 of the 72 quadrats sampled contained no Zostera marina shoots. Populations of Gracilariopsis within these intertidal eelgrass beds consisted primarily of thalli partially embedded in the sediment. All of the Gracilariopsis thalli found within the bay had settled on the benthos as opposed to forming free-floating mats. Gracilariopsis distribution was not uniform along the length of Tomales Bay; the alga increased in abundance away from the mouth of the estuary (Fig. 2).

Both among and within site variability of Gracilariopsis abundance was high (Fig. 3). Average biomass of Gracilariopsis across sites was $326 \mathrm{~g} \mathrm{~m}^{-2}$ (SE 97), with a maximum average site value of $1780 \mathrm{~m}^{-2}$ (SE 362). At 


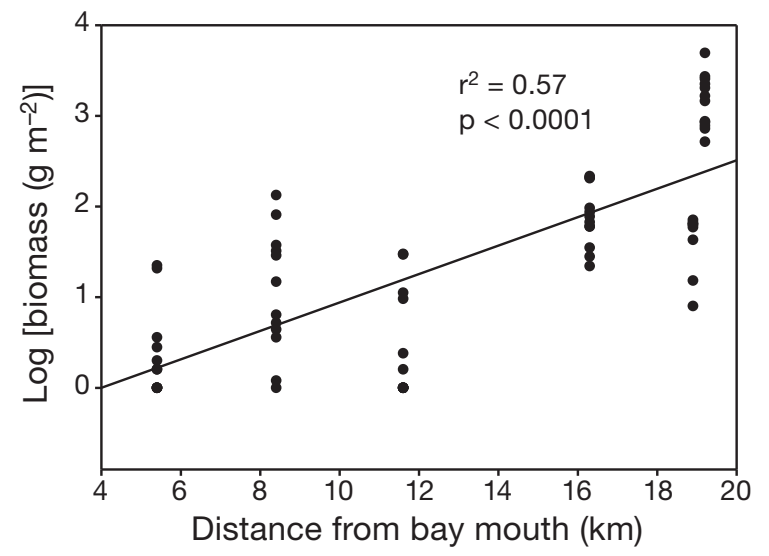

Fig. 2. Relationship between Gracilariopsis biomass ( $\mathrm{n}=72 \mathrm{~m}^{2}$ quadrats) and distance from the mouth of Tomales Bay


Fig. 3. Relationship between Gracilariopsis biomass and Zostera marina shoot density in $12 \mathrm{~m}^{2}$ quadrats at each distribution and abundance survey site. Linear trendlines are shown where correlation analysis indicated a significant relationship and adjusted $\mathrm{r}^{2}$ values are reported. Note difference in scales on $\mathrm{x}$ axes
Cypress Grove Preserve, half of the sampled quadrats contained no Gracilariopsis. In contrast, at Tomasini Cove, near the head of the bay, Gracilariopsis was found in all 12 quadrats, averaging $1780 \mathrm{~g} \mathrm{~m}^{-2}$ wet mass, reaching a maximum of $4944 \mathrm{~g} \mathrm{~m}^{-2}$. Sites with highest macroalgal mass (i.e. Marconi Cove and Tomasini Cove) had significantly negative relationships between eelgrass shoot density and seaweed biomass (Fig. 3). While a negative relationship between increasing macroalgal density and decreasing eelgrass density existed at the among-sites scale, the goodness of fit for this trend was weak ( $\left.p=0.049, r^{2}=0.19\right)$ and Gracilariopsis mass explained $<20 \%$ of variation in eelgrass shoot density.

\section{Enclosure/exclosure experiment}

By the conclusion of the experiment, mean $( \pm \mathrm{SE}) \%$ organic and nutrient content of sediments had decreased across all plots regardless of macroalgal treatment. Final measurements of sediment organic content averaged across the study site (mean $=3.00 \pm$ $0.06 \%$ ) were lower (independent samples $t$-test, $\mathrm{p}=$ $0.057)$ than initials $($ mean $=3.41 \pm 0.13 \%)$; however, these values did not differ between treatments (1-factor ANOVA, $\mathrm{df}=4, F=1.023, \mathrm{p}=0.42$ ). Similarly, final sediment $\% \mathrm{~N}$ and $\% \mathrm{C}$ tended to be lower (mean = $0.087 \pm 0.003 \% \mathrm{~N}$ and mean $=0.774 \pm 0.023 \% \mathrm{C}$ ) than initial values $($ mean $=0.102 \pm 0.011 \% \mathrm{~N}$ and mean $=$ $0.851 \pm 0.114 \% \mathrm{C}$ ), though not significantly (independend samples $t$-test, $\mathrm{p}=0.11$ for $\% \mathrm{~N}$ and $\mathrm{p}=0.41$ for $\% \mathrm{C}$ ). Final sediment $\% \mathrm{~N}$ and $\% \mathrm{C}$ did not differ between treatments (1-factor ANOVA, df $=4, F=$ $1.220, \mathrm{p}=0.33$ and $\mathrm{df}=4, F=1.595, \mathrm{p}=0.21$, respectively). Redox potential $($ mean $=161.7 \pm 9.4 \mathrm{mV}$ ) showed no relationship to Gracilariopsis treatment (1-factor ANOVA, $\mathrm{df}=4, F=1.118, \mathrm{p}=0.43$ ).

All macroalgae remaining in the treatment plots were collected at the end of the experiment. Macroalgae were lost throughout the 3 mo study period due to natural senescence as well as escape from the mesh netting-sediment interface. An average of $31 \mathrm{~g}$ (SE 18) of the low density treatment $\left(350 \mathrm{~g} \mathrm{~m}^{-2}\right)$ remained in the plots at the end of the experiment, representing $4 \%$ of the biomass added at the outset. In the high density treatment $\left(1700 \mathrm{~g} \mathrm{~m}^{-2}\right), 699 \mathrm{~g}$ (SE 72) remained, accounting for $21 \%$ of the biomass added at the outset. Gracilariopsis was usually found anchored on small pebbles or imbedded partially into the soft-sediment of Tomales Bay. However, when macroalgae were weighed for the experiment, all debris was removed to avoid confounding total weight, and the added algae were not embedded within the sediments of the treatment plots. Losses of macroalgae resulted in treat- 
ments that were less dense than planned (i.e. the treatment efficacy was low) and thus our tests of macroalgal effects were conservative.

Light reaching established shoots at the eelgrass canopy height, ( $\sim 50 \mathrm{~cm}$ above the benthos) was similar (mean PAR $=1644 \mu \mathrm{mol}$ photons $\mathrm{m}^{-2} \mathrm{~s}^{-1}$ ) across treatments (nearly $40 \%$ of surface irradiance, 1 -factor ANOVA, $\mathrm{df}=4, F=2.838, \mathrm{p}=0.05$, Fig. 4). In contrast, PAR values measured near the benthos were lower than those taken at the top of the eelgrass canopy and differed significantly between treatments (2-factor ANOVA, $p<0.001$ for both depth of light reading and treatment; Fig. 4). The open bed plots without any PVC caging had the highest PAR values near the benthos (675 $\mu \mathrm{mol}$ photons $\mathrm{m}^{-2} \mathrm{~s}^{-1}$ ). The benthic PAR values averaged $434 \mu \mathrm{mol}$ photons $\mathrm{m}^{-2} \mathrm{~s}^{-1}$ in the cage controls compared to 248 in the macroalgal removal and 116 in the low macroalgal addition treatments, suggesting decreased light values resulted from both cage screening presence and macroalgal presence. Light reaching the benthos in the high-density macroalgal treatment was only $2 \%$ of surface irradiance, significantly lower than in both control treatments and the macroalgal removal treatments (Fig. 4, mean $=39 \mu \mathrm{mol}$ photons $\mathrm{m}^{-2} \mathrm{~s}^{-1}$ ).

A negative effect of macroalgae on eelgrass growth characteristics was detectable with the highest algal addition. Repeated measures ANOVA showed a fluctuation in eelgrass shoot density over the 3 mo sam-

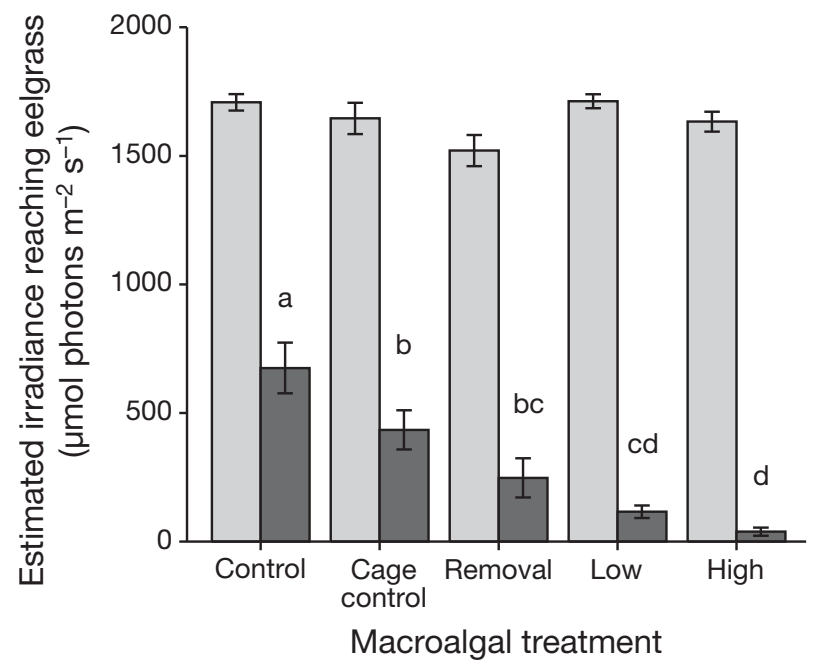

Fig. 4. Estimated mean photon irradiance reaching Zostera marina canopies $50 \mathrm{~cm}$ above the benthos $(\square)$ and new shoots $5 \mathrm{~cm}$ above benthos $(\square)$ in September 2005. Control = no manipulation, cage control = partial cage to test for artifacts of cage presence. Gracilariopsis treatments were: removal, low biomass $\left(325 \mathrm{~g} \mathrm{~m}^{-2}\right)$, high biomass $\left(1700 \mathrm{~g} \mathrm{~m}^{-2}\right)$. Means $\pm \mathrm{SE}, \mathrm{n}=6$. In the figure, the letters positioned above the bars indicate significant differences $(p<0.05$, Fisher's PLSD test) among means
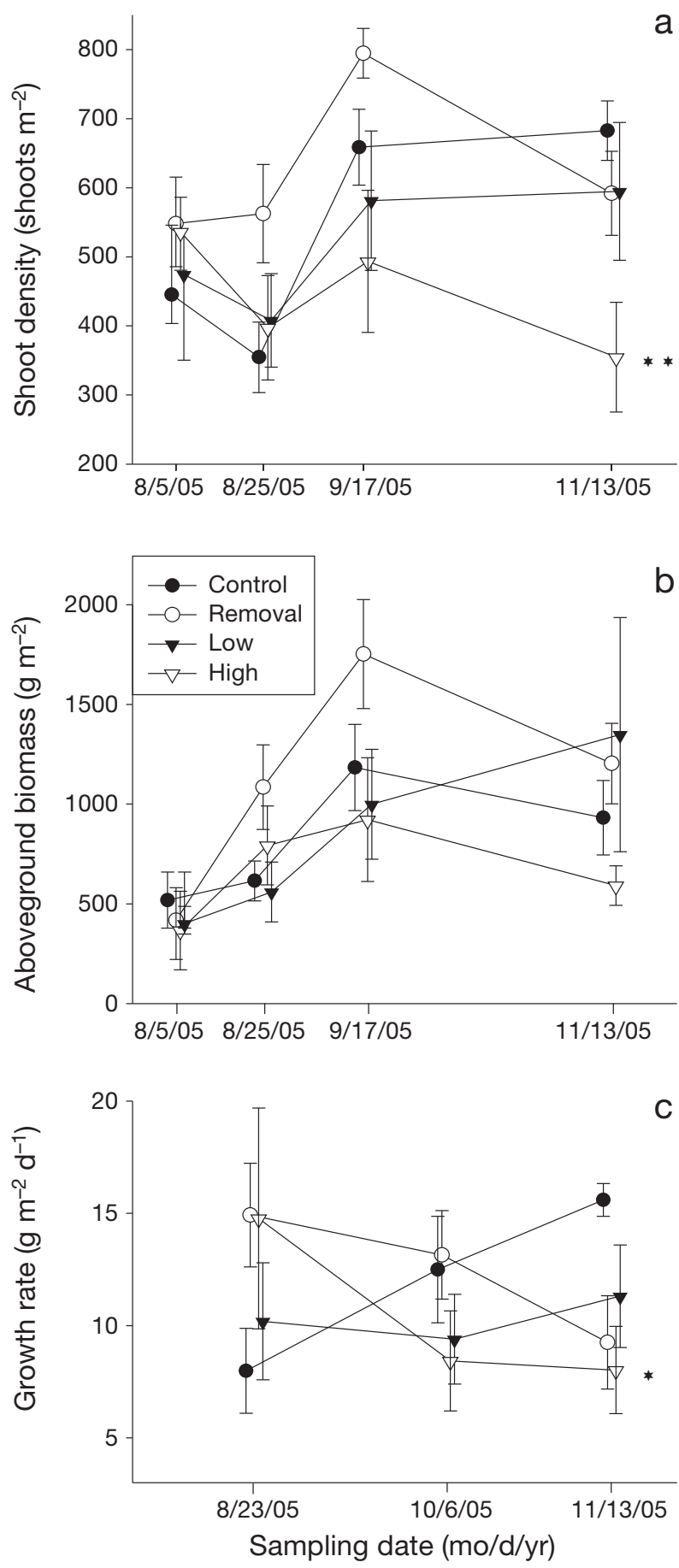

Fig. 5. Zostera marina (a) shoot density (b) shoot biomass and (c) growth rates in enclosure experiment over 3 mo ( $\mathrm{n}=6$; means \pm SE). Initial (pre-treatment) data are shown for (a) and (b). Biomass was calculated from longest leaf length using a Model 2 regression equation (see 'Material and methods'): log (aboveground biomass $[\mathrm{g}]$ ) $=2.198$ (log (longest leaf length [cm]) - 3.214. The cage control did not differ significantly from the no manipulation control and is not shown to improve ease of viewing. ${ }^{*}$ significant at $\mathrm{p}<0.05,{ }^{* *}$ significant at $\mathrm{p}<0.01$. Symbols and lines are slightly displaced horizontally to improve clarity 
pling period (Fig. 5a). From late August to midNovember, there was a trend $(p=0.069)$ of lowered shoot density with the highest addition of macroalgae, and a significant $(p=0.026)$ interaction between sampling date and macroalgal treatment, where the high macroalgal treatment decreased in shoot density over time relative to the other treatments (Table 1). Final eelgrass shoot density was significantly lower in the high density algal treatment relative to controls (Fisher's PLSD p < 0.01, Table 2, Fig. 5a), amounting to a $49 \%$ reduction compared to controls. Similar trends also occurred in aboveground biomass, with significant differences overall by date, but not by treatment,

Table 1. Repeated measures ANOVA on log transformed Zostera marina shoot density, aboveground biomass and growth rate across macroalgal treatments $(\mathrm{n}=6)$ over 3 mo

\begin{tabular}{|lrrrc|}
\hline Source & df & MS & $F$ & $\mathrm{p}$ \\
\hline Shoot density & & & & \\
Between-subject effects & & & & \\
$\quad$ Algal treatment & 4 & 0.166 & 2.491 & 0.069 \\
$\quad$ Error & 25 & 0.067 & & \\
Within-subject effects & & & & \\
$\quad$ Sampling date & 2 & 0.252 & 17.424 & $<0.001$ \\
$\quad$ Date $\times$ Treatment & 8 & 0.037 & 2.527 & 0.026 \\
$\quad$ Error & 50 & 0.014 & & \\
& & & & \\
Aboveground biomass & & & & \\
Between-subject effects & & & & \\
$\quad$ Algal treatment & 4 & 0.226 & 1.570 & 0.213 \\
$\quad$ Error & 25 & 0.144 & & \\
Within-subject effects & & & & \\
$\quad$ Sampling date & 2 & 0.321 & 10.434 & 0.001 \\
$\quad$ Date $\times$ Treatment & 8 & 0.038 & 1.227 & 0.312 \\
$\quad$ Error & 50 & 0.031 & & \\
$\quad$ Growth rate & & & & \\
Between-subject effects & & & & \\
$\quad$ Algal treatment & 4 & 0.026 & 0.401 & 0.806 \\
$\quad$ Error & 18 & 0.064 & & \\
Within-subject effects & & & & \\
$\quad$ Sampling date & 2 & 0.012 & 0.262 & 0.718 \\
$\quad$ Date $\times$ Treatment & 8 & 0.120 & 2.605 & 0.037 \\
Error & 36 & 0.046 & & \\
\hline
\end{tabular}

Table 2. Summary of 1-factor ANOVAs assessing the significance of macroalgal treatment on log transformed Zostera marina shoot density, aboveground biomass and growth rate at the conclusion of the enclosure/exclosure experiment

\begin{tabular}{|lcccc|}
\hline Variable & df & MS & $F$ & $\mathrm{p}$ \\
\hline Shoot density & 4 & 0.125 & 4.682 & 0.006 \\
Aboveground biomass & 4 & 0.094 & 1.515 & 0.228 \\
Growth rate & 4 & 0.182 & 3.452 & 0.025 \\
\hline
\end{tabular}

and a non-significant trend of reduced biomass in the high density algal treatment over time (Fig. 5b, Table 1). However, a 1-factor ANVOA of final eelgrass biomass showed that algal treatment effects were not significant (Table 2).

The high macroalgal treatment had negative effects on Zostera growth rates. While growth rates were not significantly different overall across sampling dates (Table 1; grand means $[ \pm \mathrm{SE}]$ of $11.93 \pm 1.42,11.31 \pm$ 1.07 , and $12.60 \pm 1.58 \mathrm{~g} \mathrm{~m}^{-2} \mathrm{~d}^{-1}$ in each consecutive sampling month), there was a significant interaction of macroalgal treatment with time $(p=0.037$; Table 1$)$. Further, the 1-factor ANOVA of final eelgrass growth rates showed differences among treatments (Table 2), with significantly lower values in the high density algal treatment compared to both control treatments (Fisher's PLSD, $\mathrm{p}<0.05$, Fig. 5c), and intermediate values in the removal and low density treatments.

\section{DISCUSSION}

The impacts of the macroalga Gracilariopsis sp. on Zostera marina in Tomales Bay were both scale and density dependent. On a system scale, we found limited evidence of macroalgal impact; a significant negative relationship explained $<20 \%$ of the variability in eelgrass shoot density across all survey sites. However, it should be noted that our survey represents a snapshot in time, and we do not know how long macroalgae were present at any one quadrat-sampling location. With repeated, high density additions of macroalgae over time in our enclosure/exclosure experiment, this macroalga was capable of significantly decreasing the shoot density and growth rate of $Z$. marina, with a similar (non-significant) tendency for aboveground biomass.

Light limitation may be the mechanism accounting for eelgrass declines in the high algal treatment. Reduced production of new shoots in Zostera marina is likely caused by low light levels reaching newly recruiting shoots, reducing photosynthesis and thereby reducing total shoot density (Hauxwell et al. 2001, Havens et al. 2001). Newly recruiting shoots under macroalgal mats in our highest algal treatment received low light intensities nearing compensation levels for $Z$. marina (10 $\mu \mathrm{mol}$ photons $\mathrm{m}^{-2} \mathrm{~s}^{-1}$, Dennison \& Alberte 1982). Maximum macroalgal loads were detrimental to existing shoots as well, as evidenced by the decline in growth rate. Light limitation may have contributed to a decreased photosynthetic activity which resulted in slower shoot growth. In view of lowered growth rates, a longer period of dense algal mat presence would very likely have led to significant biomass decreases as well. 
Modeling by Cioffi \& Gallerano (2006) demonstrated that the detrimental impact of macroalgal mats on Zostera marina is not due to nutrient competition, but rather light limitation to the underlying eelgrass. Hauxwell et al. $(2001,2003)$ also identified light limitation due to macroalgal canopies as the causal mechanism behind decreases in eelgrass shoot densities and growth rates. Our study from Tomales Bay adds to the emerging view that reduced eelgrass shoot density through the loss of new shoot establishment occurs with high macroalgal densities. While we documented severe reductions in light availability under the Gracilariopsis mats, further research would be necessary to evaluate the effects on different age classes of eelgrass shoots.

Macroalgal mats of comparable densities to those used in this study cause a negative impact on seagrass over short time scales. Irlandi et al. (2004), using macroalgal treatment plots with loads of $2000 \mathrm{~g} \mathrm{~m}^{-2}$ wet weight, observed $\sim 25 \%$ reduction in above-ground biomass in seagrass plots in 2 to 3 mo. Cummins et al. (2004) documented declines in seagrass biomass and infaunal assemblages after 3 mo in response to macroalgal loads of $4500 \mathrm{~g} \mathrm{~m}^{-2}$ wet weight. Despite the limited time scale of this study ( $3 \mathrm{mo}$ ), our results and observations obtained during a single growing season suggest that high macroalgal loads impede establishment of new eelgrass shoots and slow the growth of existing shoots. Furthermore, the very low biomass of added macroalgae remaining in our treatment plots at the end of the study indicates conservative application of our intended treatment levels. Given that we found an effect in multiple eelgrass response variables despite significant algal leakage suggests that the true impacts of these high density macroalgal accumulations in Tomales Bay could be much larger than reported in this study.

Macroalgal canopy height and mat diameter are likely to influence the strength of the negative impact of macroalgae on seagrasses. Mats of small size may be more subject to translocation and cause only limited reduction of light penetration to seagrass, while mats of a certain diameter, height or biomass can remain stationary and cause severe light limitation. Holmquist (1997) observed that small diameter $(<0.25 \mathrm{~m})$ mats had no detrimental impacts on seagrass, while larger macroalgal mats (1.0 m diameter) caused decreases in seagrass density and growth. Similar results were shown by Hauxwell et al. (2001) who found that algal canopy heights $>9-12 \mathrm{~cm}$ led to greater seagrass loss than shorter algal canopy heights in Waiquot Bay, Massachusetts. In our enclosure experiment, neither the low density macroalgal treatment nor the removal of existing macroalgae significantly impacted eelgrass, suggesting that mean macroalgal loads (based on coarse among-site averaging) currently have no discernable impact at fine scales $\left(\sim 1 \mathrm{~m}^{2}\right)$ on eelgrass survival in Tomales Bay. Our results, in conjunction with these previous studies, suggests a threshold response of seagrass to macroalgal loads in which the biomass, canopy height, diameter and longevity of the macroalgal mat will all play roles in determining the level of impact on the underlying seagrass.

The transition from eelgrass to a macroalgal dominated system has not yet occurred in Tomales Bay. Our results show a low, but highly variable, average abundance of Gracilariopsis $\left(326 \pm 97 \mathrm{~g} \mathrm{~m}^{-2}\right.$ ) throughout the length of Tomales Bay, increasing away from the mouth of the estuary. This gradient in algal abundance could be linked to a newly identified source of nitrogen near the Lagunitas-Olema Creek inflow at the bay head (Huntington 2006). Similarly, eelgrass aboveground biomass increases towards the bay head and may impact the retention of macroalgal biomass. Notable macroalgal accumulations do occur within specific eelgrass beds near the bay head (e.g. Marconi Cove and Tomasini Cove), where loads can exceed $4900 \mathrm{~g} \mathrm{~m}^{-2}$ (wet weight) (Huntington 2006). Additionally, the CDFG reported Gracilariopsis abundances as high as 3100,1680 , and $1350 \mathrm{~g} \mathrm{~m}^{-2}$ (wet weight) between 2000 and 2004 at 3 different eelgrass beds along the eastern shore of Tomales Bay where prevailing eastward winds likely blow mats into shallow accumulations along eastern coves. These localized abundances are high enough to cause declines in the underlying eelgrass at a fine scale $\left(\sim 1 \mathrm{~m}^{2}\right)$. Further increases in macroalgal abundance coupled with increased persistence and homogenous cover could result in significant eelgrass declines detectable at the system scale.

It is difficult to restore ecosystems once they have undergone shifts in species composition and habitat structure (Scheffer et al. 2001, Folke et al. 2004). In the case of seagrasses, recovery may be impossible (Kendrick et al. 2002). This reinforces the need to be able to detect and manage gradual changes to seagrass systems that may reduce total system resilience (Scheffer et al. 2001, Cardoso et al. 2004). While the mobile and variable nature of macroalgal mats makes predicting future eelgrass loss challenging, Tomales Bay presents a unique opportunity to monitor eelgrass survivorship before a phase shift occurs. Changes in community composition at a primary producer level, though they may be subtle seasonal changes or at small scales, may be useful early-warning responses to system-wide shifts. Monitoring efforts in the region should include targeted surveys of Gracilariopsis cover within eelgrass beds coupled with water quality monitoring in order to best manage the seagrass resources in Tomales Bay. 
Acknowledgements. For their assistance, we thank B. Becker, A. Perron-Burdick, J. Kertesz, D. Reineman, B. Reineman, L. Reynolds, and R. Watanabe. Field support was provided by the Audubon Cypress Grove Preserve, the National Park Service and the California Department of Fish and Game. Thanks to Moss Landing Marine Laboratories for use of their CHN analyzer. Special thanks to P. Fong and F. Wilkerson for their comments, advice and editorial reviews. This manuscript was greatly strengthened by the comments of 2 anonymous reviewers. This research was funded through an EPA STAR fellowship and a US Fish and Wildlife Foundation Budweiser Conservation Fellowship to B.E.H.

\section{LITERATURE CITED}

Bell SS, Hall MO (1997) Drift macroalgal abundance in seagrass beds: investigating large-scale associations with physical and biotic attributes. Mar Ecol Prog Ser 147: 277-283

Bellwood DR, Hughes TP, Folke C, Nystrom M (2004) Confronting the coral reef crisis. Nature 429:827-833

Borum J (1996) Shallow water and land/sea boundaries. In: Jørgenson BB, Richardson K (eds) Eutrophication in coastal marine systems. American Geophysical Union, Washington, DC, p 179-203

Bostrom C, Bonsdorff E (2000) Zoobenthic community establishment and habitat complexity - the importance of seagrass shoot-density, morphology and physical disturbance for faunal recruitment. Mar Ecol Prog Ser 205:123-138

Boyer KE, Fong P (2005) Macroalgal mediated transfers of water column nitrogen to intertidal sediments and salt marsh plants. J Exp Mar Biol Ecol 321:59-69

Brun FG, Hernandez I, Vergara JJ, Perez-Llorens JL (2003) Growth, carbon allocation and proteolytic activity in the seagrass Zostera noltii shaded by Ulva canopies. Funct Plant Biol 30:551-560

Bruno JF, Bertness MD (2001) Habitat modification and facilitation in benthic marine communities. In: Bertness MD, Gaines SD, Hay ME (eds) Marine community ecology. Sinauer Associates, Sunderland, MA, p 201-218

> Cardoso PG, Pardal MA, Lillebo AI, Ferreira SM, Raffaelli D, Marques JC (2004) Dynamic changes in seagrass assemblages under eutrophication and implications for recovery. J Exp Mar Biol Ecol 302:233-248

Cioffi F, Gallerano F (2006) From rooted to floating vegetal species in lagoons as a consequence of the increases of external nutrient load: an analysis by model of the species selection mechanism. Appl Math Model 30:10-37

Cummins SP, Roberts DE, Zimmerman KD (2004) Effects of the green macroalga Enteromorpha intestinalis on macrobenthic and seagrass assemblages in a shallow coastal estuary. Mar Ecol Prog Ser 266:77-87

Dayton PK (1972) Toward an understanding of community resilience and the potential effects of enrichments to the benthos at McMurdo Sound, Antarctica. In: Parker BC (ed) Proceedings of the colloquium on conservation problems in Antarctica. Allen Press, Lawrence, KS, p 81-95

Dennison WC, Alberte RS (1982) Photosynthetic response of Zostera marina L. (eelgrass) to in situ manipulations of light intensity. Oecologia 55:137-144

Folke C, Carpenter S, Walker B, Scheffer M, Elmqvist T, Gunderson L, Holling CS (2004) Regime shifts, resilience, and biodiversity in ecosystem management. Annu Rev Ecol Syst 35:557-581

Fourqurean JW, Moore TO, Fry B, Hollibaugh JT (1997) Spatial and temporal variation in $\mathrm{C}: \mathrm{N}: \mathrm{P}$ ratios, $\delta \mathrm{N}^{15}$ and $\delta \mathrm{C}^{13}$ of eelgrass Zostera marina as indicators of ecosystem pro- cesses, Tomales Bay, California, USA. Mar Ecol Prog Ser 157:147-157

Gerard VA (1999) Positive interactions between cordgrass, Spartina alterniflora, and the brown alga, Ascophyllum nodosum ecad scorpioides, in a mid-Atlantic coast salt marsh. J Exp Mar Biol Ecol 239:157-164

Hauxwell J, Cebrian J, Furlong C, Valiela I (2001) Macroalgal canopies contribute to eelgrass (Zostera marina) decline in temperate estuarine ecosystems. Ecology 82:1007-1022

> Hauxwell J, Cebrian J, Valiela I (2003) Eelgrass Zostera marina loss in temperate estuaries: relationship to landderived nitrogen loads and effect of light limitation imposed by algae. Mar Ecol Prog Ser 247:59-73

> Havens KE, Hauxwell J, Tyler AC, Thomas S and others (2001) Complex interactions between autotrophs in shallow marine and freshwater ecosystems: implications for community responses to nutrient stress. Environ Pollut 113:95-107

> Holmquist JG (1997) Disturbance and gap formation in a marine benthic mosaic: influence of shifting macroalgal patches on seagrass structure and mobile invertebrates. Mar Ecol Prog Ser 158:121-130

Huntington B (2006) Is a macroalga threatening seagrass survival? Responses of seagrass to increased macroalgal dominance in Tomales Bay, CA. MA thesis, San Francisco State University, San Francisco, CA

> Irlandi EA, Orlando BA, Biber PD (2004) Drift algae-epiphyteseagrass interactions in a subtropical Thalassia testudinum meadow. Mar Ecol Prog Ser 279:81-91

Kendrick GA, Aylward MJ, Hegge BJ, Cambridge ML, Hillman K, Wyllie A, Lord DA (2002) Changes in seagrass coverage in Cockburn Sound, Western Australia between 1967 and 1999. Aquat Bot 73:75-87

Koch MS, Mendelssohn IA, McKee KL (1990) Mechanism for the hydrogen sulfide-induced growth limitation in wetland macrophytes. Limnol Oceanogr 35:399-408

Lamote M, Dunton KH (2006) Effects of drift macroalgae and light attenuation on chlorophyll fluorescence and sediment sulfides in the seagrass Thalassia testudinum. J Exp Mar Biol Ecol 334:174-186

> Lee K, Dunton KH (2000) Diurnal changes in pore water sulfide concentrations in the seagrass Thalassia testudinum beds: the effects of seagrasses on sulfide dynamics. J Exp Mar Biol Ecol 255:201-214

- McGlathery KJ (2001) Macroalgal blooms contribute to the decline of seagrass in nutrient-enriched coastal waters. J Phycol 37:453-456

> Schaffelke B, Mellors J, Duke NC (2005) Water quality in the Great Barrier Reef region: responses of mangrove, seagrass and macroalgal communities. Mar Pollut Bull 51: 279-296

> Scheffer M, Carpenter S, Foley JA, Folke C, Walker B (2001) Catastrophic shifts in ecosystems. Nature 413:591-596

Short FT, Burdick DM (1996) Quantifying eelgrass habitat loss in relation to housing development and nitrogen loading in Waquoit Bay, Massachusetts. Estuaries 19:730-739

Short FT, Wyllie-Echeverria S (1996) Natural and human-induced disturbance of seagrasses. Environ Conserv 23: 17-27

Spratt JD (1981) Status of Pacific herring, Clupea harengus pallasii, resource in California 1972 to 1980. Cal Fish Game Fish Bull 171: 1-104

Terrados J, Duarte CM, Kamp-Nielsen L, Agawin NSR and others (1999) Are seagrass growth and survival constrained by the reducing conditions of the sediment? Aquat Bot 65:175-197

> Thomsen MS, McGlathery K (2006) Effects of accumulations of sediments and drift algae on recruitment of sessile 
organisms associated with oyster reefs. J Exp Mar Biol Ecol 328:22-34

Tyler AC, McGlathery KJ, Anderson IC (2001) Macroalgal mediation of dissolved organic nitrogen fluxes in a temperate coastal lagoon. Estuar Coast Shelf Sci 53:155-168

Valiela I, McClelland J, Hauxwell J, Behr PJ, Hersh D, Foreman K (1997) Macroalgal blooms in shallow estuaries: controls and ecophysiological and ecosystem consequences. Limnol Oceanogr 42:1105-1118

Van Katwijk MM, Vergeer LHT, Schmitz GWH, Roelofs JGM

Editorial responsibility: Kenneth Heck,

Dauphin Island, Alabama, USA
(1997) Ammonium toxicity in eelgrass Zostera marina. Mar Ecol Prog Ser 157:159-173

Wyllie-Echeverria S, Gunnarsson K, Mateo MA, Borg JA and others (2002) Protecting the seagrass biome: report from the traditional seagrass knowledge working group. Bull Mar Sci 71:1415-1417

Zieman JC, Wetzel RG (1980) Productivity in seagrasses: methods and rates. In: Phillips RC, McRoy CP (eds) Handbook of seagrass biology. Garland Press, New York, NY, p 87-166

Submitted: March 8, 2007; Accepted: April 4, 2008

Proofs received from author(s): September 4, 2008 